\title{
KISŞILIIK ÖZELLİKLERİ VE RİSKLİ SÜRÜCÜLÜK: BİR DERLEME ÇALIŞMASI
}

\author{
Pınar BIÇAKSIZ*
}

$\ddot{O}_{z}$

Dünya genelinde ölüm nedenleri arasında her yıl gittikçe daha yüksek siralarda yer alan trafik kazaları ciddi bir halk sağlı̆̆ı meselesidir. Trafik kazalarını önleyebilmek için öncelikle bu sorunu anlamak ve açılayabilmek gerekir. Trafik kazalarının nedenleri arasında en önemlisi insan faktörüdür ve sürücülük becerileri ile davranışları olmak üzere iki ana başlıkta incelenir. Sürücülük tarzı, kişinin belli sürücülük becerileri düzeyiyle ne yapmayı seçtiği ile ilgilidir ve kişilik özelliklerinden etkilenir. Bu çalışmanın amacı riskli sürücülük tarzını açılamayı hedefleyen çalışmalarda incelenen kişilik özelliklerini tanıtmak ve bu çalışmaların bulgularını bir araya getirmektir. Bu kapsamda, trafik psikolojisi yazınında incelenen beş faktörlü kişilik modeli, treyt öfke, heyecan arama, dürtüsellik, Karanlık Üçlü kişilik özellikleri ve kontrol odağı değişkenlerinin riskli sürücülükle ilişsilerini araştıran alanyazın bu derleme çalışmasında özetlenerek sunulmaktadır.

Anahtar kelimeler: Kişilik Özellikleri, Riskli Sürücülük, Derleme

\section{PERSONALITY TRAITS AND RISKY DRIVING: A REVIEW}

\begin{abstract}
Traffic accidents, increasingly ranking among the leading causes of death worldwide, pose a serious public health issue. To be able to prevent road traffic accidents, this problem should be understood and explained first. The most significant cause of traffic accidents is the human factors in driving and it entails driving skills and behaviors. Driving style is related to what the driver chooses to do with a specific skill level and it is known that driving style is influenced by personality traits. The aim of the present study is to introduce the personality traits that are examined in the studies trying to explain risky driving style and compile the findings of these studies. In this realm, the associations of the personality variables examined in the traffic psychology literature-namely five factor model of personality, trait anger, sensation seeking, impulsivity, Dark Triad personality traits and locus of control- with risky driving are presented in the current review study.
\end{abstract}

Keywords: Personality Traits, Risky Driving, Review

* Dr. Öğr. Üyesi, Psikoloji Bölümü, Hacettepe Üniversitesi, pinarbicaksiz@hacettepe.edu.tr, ORCID: https://orcid.org/0000-0002-8376-6145 


\section{GíRiş}

Dünya genelinde ölüm nedenleri sıralamasında trafik kazaları 2012 yılında dokuzuncu sıradayken (WHO, 2014), 2016 yılında sekizinci sıraya yükselmiştir (WHO, 2018) ve 2030 yılında da beşinci sıraya yükselmesi beklenmektedir (WHO, 2008). Bu verilerin göstermekte olduğu üzere gün geçtikçe daha da ciddi bir halk sağlı̆̆ sorunu haline gelen trafik kazalarının nedenleri insan, araç ve çevreye dayalı faktörler olmak üzere üç ana kategoride incelenmektedir (Evans, 2004). Diğer koşullar sabit tutulduğunda trafik kazalarının neredeyse \%90'ında insan faktörünün ana veya yardımcı unsur olduğu bilinmektedir. $\mathrm{Bu}$ nedenle trafik kazalarını engellemek için gerekli karşı önlemlerin alınabilmesi ve müdahale programlarının geliştirilebilmesi için sürücülükte insan faktörünü açıklamak amacıyla yürütülen araştırma calışmaları büyük önem taşımaktadır.

Sürücülükte insan faktörü sürücülük performansı ve sürücülük tarzı olmak üzere iki ana başlıkta incelenmektedir (Näätänen ve Summala, 1976; Reason, Manstead, Stradling, Baxter ve Campbell, 1990). Sürücülük performansı sürücü becerileri olarak da adlandırılmakta (Evans, 1996) olup sürücülük bağlamındaki bilgi işleme ve motor becerileri içermektedir (Elander, West, ve French, 1993). Sürücülük tarzı ise sürücünün ne yapmayı seçtiği ile ilgilidir ve sürücü davranışları olarak da adlandırılmaktadır (Evans, 1996). Sürücülük bağlamında nasıl davranmayı seçtiği de bireyin genel tutum ve alışkanlarını yansıtmaktadır (Elander ve ark., 1993) ve bu nedenle de kişilik özelliklerinden etkilenmesi beklenir. Elander ve arkadaşları (1993), kalıcı bireysel özelliklerin dışarıda bırakarak trafik kazalarını açıklamaya çalışan modellerin kaza sayılarındaki varyansın çok az bir kısmını (\%10'undan daha azını) açıklayabildiğini belirterek kişilik özelliklerinin bu bağlamda çalışılmasının önemini ve olası katkısını vurgulamışlardır.

Sümer (2003) tarafından önerilen bağlamsal aracılı modelde ("contextual mediated model") kişilik özellikleri demografik özellikler, yol ve araç koşulları, denetim, kültürel faktörler (Örn., kültüre bağlı sürücülük alışkanlıkları ve inançlar) gibi değişkenlerle birlikte uzak bağlamda yer almaktadır. Uzak bağlamda yer alan bu değişkenler kazaya karışmayı, yakın bağlamda yer alan güvenli sürücülük becerileri, olumsuz sürücü davranışları, trafik kural ihlalleri, sürücü hataları, hız yapma, alkollü araç kullanma gibi aracı değişkenler üzerinden yordamaktadır. Uzak bağlam, modelde trafik kazasına karışma sonuç değişkenini dolaylı olarak etkilediği öne sürülen dışsal değişkenleri, yakın bağlam ise uzak bağlamdaki değişkenlerle kazaya karışma arasındaki ilişkiye aracılık eden ve sonuç değişkeniyle doğrudan ilişkili olduğu öne sürülen değişkenleri içermektedir. Başka 
bir deyişle, kişilik özellikleri sürücülük davranışlarıyla ilişkilidir ve bu ilişski üzerinden kazaları dolaylı olarak yordamaktadır. Alanyazında da kişilik özellikleriyle sürücülük davranışları arasındaki ilişkiyi gösteren birçok araştırma bulgusuna rastlamak mümkündür (Örn., Clarke ve Robertson, 2005; Jonah, 1997; Lajunen ve Özkan, 2005). Bu çalışmanın amacı alanyazındaki bu bulguları bir araya getirerek okuyucuya sunmaktır. İlerleyen bölümlerde trafik psikolojisi yazınında en çok çalışılmış olan kişilik özellikleri olan beş faktörlü kişilik modeli, kişilik özelliği olarak öfke (treyt öfke), heyecan arama, dürtüsellik, kontrol odağ ve Karanlık Üçlü kişilik özellikleriyle sürücülükle ilgili değişkenler arasındaki ilişkileri inceleyen çalışmaların bulguları sunulacaktır.

\section{BEŞ FAKTÖRLÜ KISŞİLIKK MODELİ}

Büyük Beşli (“Big Five”) kişilik modeli Goldberg (1993) tarafından, İngilizce dilindeki kişilik özelliklerini yansıtan sıfatlara yönelik çalışmalar sonucu geliştirilmiştir. Bu modelde beş temel kişilik faktörü dişarıya aç1lım ("surgency"), uyumluluk/geçimlilik ("agreeableness"), sorumluluk ("conscientiousness"), duygusal tutarl11ı ("emotional stability") ve akıl ("intellect”) olarak önerilmiştir. Benzer bir yöntemle Costa ve McCrae (1992) de beş faktörlü kişilik modelini ("five factor model of personality") önermiştir ve bu modelde de öne sürülen kişilik faktörleri dişadönüklük ("extraversion”), sorumluluk ("conscientiousness"), uyumluluk/geçimlilik ("agreeableness"), duygusal tutarsızlık ("neuroticism") ve gelişime açıklık ("openness to experience”) faktörleridir. Dışadönüklük faktörü, atılganlık, aktif ve sosyal olma, heyecan arama ve dürtüsellik ile tanımlanır (Costa ve McCrae, 1992; Eysenck ve Eysenck, 1968; Eysenck ve Eysenck, 1975). Sorumluluk faktörünün tanımı ise başarı yönelimi, düzen, görev bilinci, yetkinlik, öz-disiplin ve tedbirli olma gibi unsurları içermektedir (Clarke ve Robertson, 2005). Uyumluluk/geçimlilik faktörü kişilerarası ilişkilerle en yakından ilişkili olan faktör olup yardımsever ve affedici olma, kibar, anlayışlı ve diğer insanlara güvenebilme ile ilişkilidir (Dahlen, Edwards, Tubré, Zyphur, ve Warren, 2012). Duygusal tutarsızlık ise kaygı, düşmanlık (“hostility”), depresyon, öz-farkındalık ve dürtüsellikle ilişkilidir (Eysenck, 1970) ve duygulanım süreçleriyle en yakından ilgili olan faktördür. Son olarak gelişime açıklık faktörü ise hayal gücü, sanatsal duyarlılık, açık fikirlilik, özgünlük ve merak ile ilişkilidir (Dahlen ve ark., 2012).

Beş faktörlü kişilik modelinin sürücülükle ilişkileri 1960'li yıllardan beri incelenmektedir. Örneğin, dışadönüklüğün kazaya karışmayla ilişkili olduğu rapor edilmiştir (Craske, 1968; Loo, 1979). Duygusal tutarsızlık ve kazaya karışma arasında da pozitif yönlü ilişki bulunmuştur (Mayer ve Treat, 1977; Selzer, Rogers, 
ve Kern, 1968). Dişadönüklük ile kural ihlalleri arasında da istatistiksel olarak anlamlı ilişki bulunmuştur (Eysenck ve Eysenck, 1975). Ancak 1990'lara kadar yürütülen birçok çalışma olmasına rağmen bu çalışma bulgularının da tutarsız sonuçlar verdiği görülmüştür ve bu tutarsız bulgu örüntüsünün nedeninin bu çalışmalardaki kontrol eksikliği olabileceği öne sürülmüştür (Elander, ve ark., 1993). Bu çalışmalarda dışadönüklük ve duygusal tutarsızlığın maruz kalma ile ilişkisinin hesaba katılmadığını, yani bu kişilik değişkenlerinin bireylerin daha çok trafik ortamında olmasıyla ilişkili olabileceğinin, hesaba katılmadığını belirtmişlerdir. Dahlen ve arkadaşları da beş faktörlü kişilik modeli faktörleriyle motorlu araç kazasına karışma arasındaki bulgulardaki tutarsız örüntünün trafik bağlamında çok fazla karıştırıcı ve aracı değişkenin olmasından kaynaklandığını öne sürmüşlerdir (Dahlen ve ark., 2012). Buna örnek olarak da kişilik özelliklerinin sürücülerin saldırgan sürücülük davranışlarını etkileyebileceğini ve bu tür davranışların kazaya karışmaya yol açabileceğini önermişlerdir.

Beş faktörlü kişilik modeli ve kazaya karışma arasındaki ilişkileri inceleyen çalışmaların meta-analizini yürüten Clarke ve Robertson (2005), dişadönüklük, sorumluluk ve uyumluluk/geçimlilik kişilik özelliklerinin trafik kazasına karışmayla ilişkili olduğunu ve bu ilişkilerin geçerlik genellemesi ("validity generalization") gösterdiğini rapor etmiştir. $\mathrm{Bu}$ bulgulara göre dişadönüklük arttıkça, sorumluluk ve uyumluluk/geçimlilik ise azaldıkça kazaya karışma sayısı artmaktadır. Clarke ve Robertson (2005) dişadönüklük kişilik özelliğinin, sürücüleri özellikle monoton sürüş koşullarında yorgunlukla ilgili sürücü hatalarına ve risk alma davranışlarına meyilli kılacağını ve bu nedenle kazaya karışma değişkeniyle olumlu yönlü ilişki göstermiş olabileceğini önermektedir. Sorumluluk kişilik özelliğinin ise kazaya karışmayla ilişkili olduğu bulunan düşük öz-kontrol, kayıtsızlık, otoriteye ve sosyal düzene saygısızlık ve dürtüsellik gibi özelliklerle olumsuz yönlü bağlantısı nedeniyle kazaya karışma değişkeniyle olumsuz yönlü ilişsili göstermiş olabileceğini belirtmişlerdir. Aynı şekilde uyumluluk/geçimlilik kişilik özelliğinin de kazaya karışmayla ilişsili kavgacılık, düşmanlık ve saldırganlık gibi özelliklerle olumsuz yönlü ilişkileri nedeniyle kaza sayısıyla olumsuz yönlü bağlantı beklemişlerdir.

Görece yeni bir araştırmada, Demir, Demir ve Özkan (2016), beş faktörlü kişilik modeli faktörlerinin sürücü öfkesiyle ilişkisini inceleyen çalışmaların metaanalizini yapmışlardır. Dışadönüklük, uyumluluk/geçimlilik, sorumluluk ve gelişime açılık kişilik özelliklerinin sürücü öfkesiyle ortalama korelasyonları istatistiksel olarak anlamlı bulunmuştur. $\mathrm{Bu}$ ilişkilerin hepsi pozitif yönlü 
ilişkilerdir. $\mathrm{Bu}$ bulgulardan sorumluluk ve uyumluluk/geçimlilik kişilik özellikleriyle ilgili olanlar Clarke ve Roberts (2005) bulgularıla paraleldir ancak dışadönüklük kişilik özelliğiyle ilgili olan bulgu bahsi geçen meta-analiz çalışmasınınkiyle ters yönlüdür. Ancak dikkat edilmelidir ki bu çalışmadaki sonuç değişkeni kazaya karışmayla ilişkili olan sürücü öfkesidir, yani kazaya karışma değişkeninin kendisi değildir. Ancak sürücü öfkesinin kazaya karışmayla pozitif yönlü ilişkileri (Deffenbacher, 2016) göz önünde bulundurulduğunda, dışadönüklügün de sürücü öfkesiyle pozitif yönlü ilişki göstermesi beklenmektedir.

Yürütülen en yakın tarihli meta-analiz çalışmasında (Akbari ve ark., 2019), aralarında beş faktörlü kişilik modelinin de yer aldığ kişilik özellikleriyle riskli sürücülükle ilgili değişkenler arasındaki ilişkileri inceleyen çalışmalar sentezlenmiştir. Bu meta-analiz çalışmasında uyumluluk/geçimlilik kişilik özelliği ile riskli sürücülük arasında negatif yönlü bir ilişki, duygusal tutarsızlıkla ise pozitif yönlü bir ilişki rapor edilmiştir. Ancak sorumluluk, dişadönüklük ve gelişime açıklık ile riskli sürücülük arasında istatistiksel olarak anlamlı ilişki tespit edilmemiştir.

Türk sürücü örnekleminde Sümer, Lajunen ve Özkan (2005) tarafindan yürütülen bir çalışmada beş faktörlü kişilik modelinin olumsuz/sapkın sürücü davranışları aracılığıyla kazaya karışmayla ilişkisi incelenmiştir. Uyumluluk/geçimlilik kişilik özelliğinin bu çalışmada da kazaya karışmayla aracılı/dolaylı ilişkisi ve olumsuz/sapkın sürücü davranışlarıyla da negatif yönlü ilişkisi rapor edilmiştir. Araştırmacılar bu bulguları, düşük uyumluluk/geçimlilik düzeyine sahip sürücülerin yüksek uyumluluk/geçimlilik düzeyine sahip sürücülere kıyasla saldırgan sürücülük, trafikte öç alma davranışları, diğer sürücülerle iletişim problemleri yaşama olasıllğı ve güvenlikle ilgili kurallara uymama eğilimlerinin daha yüksek olmasıyla açıklamışlardır. Benzer şekilde sorumluluk kişilik özelliğinin de olumsuz/sapkın sürücü davranışlarıyla negatif yönlü ilişkisi ve kazaya karışmayla aracılı/dolaylı ilişkisi rapor edilmiştir ve bunun nedeninin de sorumluluk düzeyi yüksek sürücülerin sosyal sorumluluk ve performans normlarına duyarlı olmaları (Arthur ve Graziano, 1996) olabileceğini öne sürmüşlerdir. Dışadönüklük ve duygusal tutarsızlık kişilik özellikleri de olumsuz/sapkın sürücü davranışlarıyla görece zayıf ama pozitif yönlü ilişkili ve kazaya karışmayla da dolaylı/aracılı olarak ilişkili bulunmuştur. Son olarak gelişime açıklık kişilik özelliği de olumsuz/sapkın sürücü davranışlarıyla negatif yönlü ilişkili, ancak kazaya karışmayla pozitif yönlü ilişkili bulunmuştur ve beş faktör içinde kazaya karışmayla aracısız ilişkisi olan tek faktördür. $\mathrm{Bu}$ birbirine karşıt bulguları ise 
araştırmacılar gelişime açıklık kişilik özelliğinin çok katmanlı yapısı olmasına ve bu katmanlardan kimilerinin kazaya karışmayla pozitif yönlü kimilerininse negatif yönlü ilişkili olabileceğiyle açıklamışlardır ve bunun gelecekte yürütülecek araştırmalarda netleştirilmesi gereken bir unsur olduğunu da belirtmişlerdir. Özetle, bu çalışmada beş faktörlü kişilik modelindeki tüm faktörler olumsuz/sapkın sürücü davranışlarıyla ilişkili bulunmuştur ancak en güçlü ilişkiyi sorumluluk kişilik özelliği göstermiştir. Ayrıca, bu çalışmanın sorumluluk ve uyumluluk/geçimlilik kişilik özellikleriyle ilgili bulguları yukarıda bahsi geçen iki meta-analiz çalışmasıyla da uyumludur, dışadönüklük ile bulgularıysa sadece Clarke ve Robertson (2005) tarafından yürütülen meta-analiz çalışmasının bulgularıyla uyumludur.

Genel olarak bakıldığında beş faktörlü kişilik özellikleri arasından sorumluluk ve uyumluluk/geçimlilik faktörlerinin olumsuz/sapkın sürücü davranışları, sürücü öfkesi ve kazaya karışma değişkenleriyle negatif yönlü ilişkisinin olduğu ve bu ilişkinin de diğer üç faktöre kıyasla alanyazında daha tutarlı bir örüntüye sahip olduğu söylenebilir. Dişadönüklük kişilik özelliğinin ise güvenli sürücülüğü olumsuz etkileyebilecek dürtüsellik ve heyecan arama gibi özelliklerle, hem de olumlu etkileyebilecek pozitif duyumsall1k ("positive affectivity") ve sosyal uyum gibi özelliklerle ilişkileri (Clarke ve Robertson, 2005) nedeniyle görece daha tutarsız bir bulgular örüntüsüne sahip olduğu öne sürülebilir. $\mathrm{Bu}$ olas1 açıklamaların da gelecekte yürütülecek çalışmalarda sistematik olarak sınanması önerilebilir.

\section{TREYT ÖFKE}

Öfke, temel duygulardan biridir ve temel duyguların her biri insanın evrimsel tarihinde belirli problemlerin çözümü için programlanmış adaptasyonlar olarak görülmektedir (Izard, 1994; Plutchik, 1994). Bu bakış açısına göre öfkenin işlevi ise tehdit ve tehlike durumlarında kendini ve kendinin olanı korumak için gerekli mekanizmaları harekete geçirmektir. Algılanan tehdit sadece fiziksel veya somut olmak zorunda olmayıp kişinin güvenlik, sağlık, iyilik hali, öz-saygı, öz-değer ve statü gibi psikolojik ya da soyut kavramlarla ilgili de olabilir. Bir kişilik özelliği olarak öfke, ya da treyt öfke ("trait anger"), ise öfke duygusunu deneyimlemeye yönelik genel veya kronik eğilim olarak tanımlanmaktadır ve treyt öfke düzeyi yüksek olan bireylerin çok çeşitli durumları öfke yaratan durumlar olarak algılamaları ve bu durumlara da yüksek öfke düzeyiyle tepki vermeleri beklenmektedir (Spielberger, 1988). Spielberger (1988) tarafindan geliştirilen ve durumsal öfke ve treyt öfkenin ayrı alt boyutlar olarak ölçüldügü ölçekte, treyt öfke 
alt ölçeği durumsal öfkenin, yani öfke duygusunun, ne sıklıkla deneyimlendiğini ölçmektedir. Treyt öfke, sürücülük bağlamında belki de en çok incelenmiş kişilik özelliklerinden biridir.

Sürücülük bağlamında öfke, genellikle öfke duygusunun dışa vurulduğu saldırgan davranışlarla birlikte çalışılmıştır. Öfke düzeyi yüksek olan sürücülerin araç kullanırken daha saldırgan davranışlarda bulundukları bilinmektedir (Deffenbacher, Deffenbacer, Lynch, ve Richards, 2003). Öfkeli ve saldırgan sürücüler kendileri ve çevrelerindeki yol kullanıcıları için önemli bir risk unsuru olarak görülmektedir (Deffenbacher, 2016).

Deffenbacher ve arkadaşları (Deffenbacher, Oetting, ve Lynch, 1994) ayrıca sürücülük öfkesi ("driving anger") kavramını ortaya atmışlardır ve bu kavramın treyt öfke kavramıyla benzerlik taşıdığını ancak treyt öfke kavramına göre daha dar ve duruma dayalı olduğunu belirtmişlerdir. Sürücülük öfkesini trafikte daha geniş bir yelpazede yer alan durumlar ve olaylara daha sık ve daha yoğun şekilde öfkelenme eğilimi olarak tanımlamışlardır ve bunun da trafikte saldırgan ve riskli davranışlarla pozitif yönlü ilişkili olduğunu göstermişlerdir (Deffenbacher ve ark., 1994; 2000; 2001; 2002).

Sürücülerin trafikte hangi durumlarda ne kadar öfkelendiklerini belirlemek amaciyla geliştirilen Sürücü Öfkesi Ölçeği (Deffenbacher ve ark., 1994) diğer sürücülerin saldırgan/düşmanca hareketleri, diğer sürücülerin kural ihlalleri, trafik polisinin varlığı, diğer sürücülerin yavaş araç kullanması, trafik ortamında engellerin olması (yol yapımı vb. gibi nedenlerle) ve diğer sürücülerin saygısızlı̆̆ı/kabalığı olmak üzere altı faktörden oluşmaktadır. Yasak, Eşiyok, Başbulut ve Korkusuz (2005) tarafından Türkçe uyarlama çalışması yürütülen ölçeğin Türk sürücü örnekleminde de aynı altı-faktörlü yapıya sahip olduğu bulunmuştur. Yasak ve Eşiyok (2009) tarafından Türk sürücü örneklemiyle yürütülen çalışmada en yüksek sıklıkla öfkelenilen durum diğer sürücülerin saygısızlığı/kabalığı olarak gözlenmiştir, bunu diğer sürücülerin kural ihlalleri ve düşmanca hareketleri takip etmiştir.

Treyt öfke, durumsal öfke, sürücülük öfkesi gibi değişkenlerin saldırgan sürücülükle ilişkisini inceleyen çalışmaların meta-analizinin yapıldığı bir çalışmada korelasyonlar treyt öfke ve saldırgan sürücülük arasında .41; ve sürücülük öfkesiyle saldırgan sürücülük arasında .37 olarak rapor edilmiştir (Nesbit, Conger, ve Conger, 2007). Görece yakın tarihli bir başka meta-analiz çalışmasında da treyt öfke ve saldırgan sürücülük arasında istatistiksel olarak anlamlı pozitif yönlü ilişki 
bulunmuştur (Bogdan, Mairean, ve Havârneanu, 2016). Bu bulgular, treyt öfkenin saldırgan sürücülükle güçlü ilişkisini kanıtlar niteliktedir.

Trafik ortamında sürücülerin öfkelendiklerinde bunu hangi şekillerde ifade ettiklerini incelemek üzere yine Deffenbacher ve arkadaşları (Deffenbacher, Lynch, Oetting, ve Swaim, 2002) tarafından geliştirilen Sürücü Öfke İfadesi Envanteri de sözel saldırgan ifade, fiziksel saldırgan ifade, öfkenin araçla ifadesi ve öfkenin olumlu/uyumlu ifadesi olmak üzere dört boyuttan oluşmaktadır. Ölçeğin Türkçe uyarlama çalışması Eşiyok ve arkadaşları (Eşiyok, Yasak, ve Korkusuz, 2007) tarafindan yürütülmüştür. Bu çalışmada son beş yıl içinde trafik cezası almış olan sürücülerin almamış olanlara kıyasla trafikte öfkelerini fiziksel saldırgan davranışlarla ve araçla ifade etme eğilimlerinin daha yüksek oldukları bulunmuştur. Ayrıca her bir boyutun ortalama değerlerine bakıldığında, bu çalışmaya katılan hem kadın hem erkek sürücüler için en yüksek sıklıkla başvurulan olumsuz öfke ifadesi biçimi sözel saldırganlıktır; bunu sırasıyla öfkenin araçla ifadesi ve fiziksel saldırgan ifade takip etmektedir. Ancak bu dört boyut içinde en yüksek sıklık ortalamasına sahip olan boyut öfkenin olumlu/uyumlu ifadesidir Bu bulgulara ek olarak, çalışmadaki erkek sürücülerin fiziksel saldırganlık ve öfkenin araçla ifadesine kadın sürücülere göre istatistiksel olarak daha sık başvurdukları gözlenmiştir.

Sürücülük öfkesinin ve sürücü öfke ifadesi arasındaki ilişkilerin de incelendiği bir önceki bölümde de bahsi geçen meta-analiz çalışmasında (Demir ve ark., 2016), sürücülük öfkesinin trafikte fiziksel saldırgan ifade, sözel saldırgan ifade ve öfkenin araçla ifadesi ile pozitif yönlü; öfkenin olumlu/uyumlu ifadesi ile negatif yönlü ilişkili olduğu ve en güçlü ilişkinin sürücülük öfkesi ile sözel saldırgan ifade arasında olduğu gözlenmiştir. Ayrıca, aynı çalışmada sürücü öfkesi ile olumsuz/sapkın sürücü davranışları arasındaki ilişkileri inceleyen çalışmaların da meta-analizi yapılmıştır. Bulgular sürücülük öfkesinin kural ihlalleri, sürücü ihmal ve hataları ile istatistiksel olarak anlamlı pozitif yönlü ilişkili olduğunu ve en güçlü ilişkinin de kural ihlalleri ile olduğunu göstermiştir.

Son olarak görece en yakın tarihli meta-analiz çalışmasında (Zhang \& Chan, 2016) sürücü öfkesinin riskli sürücülük, saldırgan sürücülük, sürücü hataları, ramak kala sayısı ve kaza sayısı gibi değişkenlerle ilişkilerini inceleyen ve 1995-2015 yılları arasında yayınlanmış olan çalışmaların meta-analizi yapılmıştır. Sürücü öfkesinin çalışmaya dâhil edilen bu beş sonuç değişkeniyle de istatistiksel olarak anlamlı pozitif yönlü ilişkileri gözlenmiştir. Sürücü öfkesi ile en güçlü ilişki saldırgan sürücülük arasındaki ilişki olup bunu sırasıyla riskli sürücülük, sürücü 
hataları, ramak kala sayısı ve kaza sayısı izlemiştir. Ramak kala ve kaza sayılarının görece zayıf ilişkiler göstermiş olması sürücülük bağlamında diğer kişilik özelliklerinin de (Örn., heyecan arama, dürtüsellik) yordayıcı değişken olarak incelendiği çalışmalarla uyumludur ve Sümer (2003) tarafından önerilen bağlamsal aracılı modelin kişiliğin kazaya karışmayı olumsuz ve riskli sürücü davranışları aracılığıyla yordayacağı önermesini destekler niteliktedir.

Özetle hem genel hem de sürücülük bağlamında ölçülen treyt öfke saldırgan sürücülükle pozitif yönlü ilişkilidir ve bu bulgu birden fazla meta-analiz çalışmasının ortak sonucudur. Saldırgan sürücülüğe ek olarak kişilik özelliği olarak öfkenin riskli sürücü davranışları, sürücü hataları ve zayıf da olsa kazaya karışmayla ilişkili olduğu da bulunmuştur. Bu bulgular, sürücülük bağlamında treyt öfkenin önemini ve aynı zamanda bu kişilik özelliğinin sürücülükteki olumsuz etkilerinin azaltmaya yönelik müdahale programları geliştirilmesinin yol güvenliğine katk1 yapma potansiyelini göstermektedir.

\section{HEYECAN ARAMA VE DÜRTÜSELLIKK}

Heyecan arama kişilik özelliği, çeşitlilik gösteren, yeni, karmaşık, yoğun hisler ve deneyimler arayışında olup bunlar için fiziksel, sosyal, yasal ve ekonomik riskler almaya gönüllü olma eğilimi olarak tanımlanmaktadır ve bu kişilik özelliği dürtüsel heyecan arama ("impulsive sensation seeking") adı verilen ve Eysenck (1983)'in psikotisizm ("psychoticism”) boyutuyla yakından ilişkili olan daha geniş bir treytin parçasıdır (Zuckerman, 1994). Heyecan arama düzeyi yüksek olan bireylerin bir görev sırasında dikkatlerini seçici bir şekilde ödül ve zevk almaya yönelttikleri ifade edilmiştir (Horwath \& Zuckerman, 1993). Heyecan arama, dürtüsellikle orta düzeyde ve dışadönüklükle de zayıf düzeyde ilişkilidir (Jonah, 1997), hatta alanyazında yaygın olarak kullanılan heyecan arama ölçeklerinden biri olan Zuckerman Heyecan Arama Ölçeği'nin (Zuckerman, Kolin, Price, \& Zoob, 1964) dört faktöründen birine adını veren ketlenmenin kalkması ("disinhibition") kavramı, en genel anlamda öz-kontrolün tersi olarak tanımlanan (Monterosso \& Ainslie, 1999) dürtüsellik kavramıyla büyük ölçüde benzerlik göstermektedir. Benzer şekilde dürtüsellik kişilik özelliğinin ölçümünde sıç̧a kullanılan UPPS Dürtüsel Davranış Ölçeğinin de (Whiteside \& Lynam, 2001) dört alt boyutundan birisi heyecan aramadır. Bu iki kişilik özelliği bu kavramsal yakınlık ve benzerlik nedeniyle bu bölümde birlikte ele alınmaktadır.

Heyecan arama ve riskli sürücülük arasındaki ilişkilerin incelendiği çalışmaların Jonah (1997) tarafından sistematik derleme çalışması yapılmıştır. Bu derleme çalışması, o yııllara kadar trafik bağlamında sıkça çalışılmış olan bu kişilik 
özelliğinin riskli sürücülükle ilişkisini inceleyen çalışmaların ilk derleme ve sentezi olma özelliğine sahiptir. Bu çalışmaya dâhil edilen toplam 40 bireysel çalışmadan sadece dördünde heyecan arama ve o çalışmada ölçülmüş olan sürücülükle ilgili sonuç değişkeni arasında istatistiksel olarak anlamlı ilişki bulunmamıştır. Geriye kalan 36 çalışmada heyecan arama değişkeninin çalışmada incelenmiş olan hız yapma, alkollü araç kullanma ve trafik kural ihlalleri gibi riskli sürücülük davranışlarıyla istatistiksel olarak anlamlı ilişkisi olduğu gözlenmiştir. Ayrıca heyecan aramanın istatistiksel olarak anlamlı da olsa en zayıf ilişkileri kazaya karışma değişkeniyle gösterdiği belirtilmiştir. Bunun nedeninin de kaza sayısı değişkeninin düşük varyansı ve normal olmayan dağılımı olduğu düşünülebilir. Bu bulgu da Sümer (2003) tarafından önerilen bağlamsal aracılı modeli destekler niteliktedir. Jonah (1997) da heyecan arama ve riskli sürücülük ilişkisinin olası aracıları olduğunu ve bu psikolojik mekanizmaların belirlenmesi için araştırmaların gerekli olduğunu belirtmiştir.

Akbari ve arkadaşları (2019) tarafından yürütülen ve yukarıda bahsi geçen çalışmada aralarında heyecan aramanın da bulunduğu bazı kişilik özelliklerinin riskli sürücülükle ilişkilerini araştıran çalışmaların meta-analizi yapılmıştır. $\mathrm{Bu}$ meta-analiz çalışmasına dâhil edilen 13 çalışmanın birleştirilmiş bulgularına göre heyecan arama ve riskli sürücülük arasında istatistiksel olarak anlamlı pozitif yönlü bir ilişki bulunmaktadır. Bu sonuç da bu meta-analizden 22 y1l önce yürütülmüş olan bir önceki derleme çalışmasının (Jonah, 1997) bulgularını destekler niteliktedir.

Büyük çoğunluğu (\%87) profesyonel sürücülerden oluşan Türk erkek sürücü örneklemiyle yürütülen bir çalışmada (Sümer ve Özkan, 2002), diğer kişilik özellikleriyle birlikte heyecan arama değişkeninin de sürücülük becerileri ve davranışlarıyla ilişkileri incelenmiştir. Heyecan arama kişilik özelliğinin sollama davranışı ve kural ihlalleriyle pozitif yönlü, güvenli sürücülük becerileriyle ise negatif yönlü ilişkili olduğu gözlenmiştir ve bu da alanyazındaki diğer çalışmalarla uyumlu bir bulgudur. Buna ek olarak farklı sürücü gruplarının da heyecan arama değişkeninde istatistiksel olarak anlamlı düzeyde birbirlerinden farklılaştıkları bulunmuştur. $\mathrm{Bu}$ bulgulara göre en düşük heyecan arama düzeyi ağır vasita sürücülerinde, en yüksek heyecan arama düzeyi ise otomobil (profesyonel olmayan) sürücülerinde gözlenmiştir ve bulgunun çalışmadaki ağır vasıta sürücüsü grubun yaş ortalamasının otomobil sürücüsü gruptan çok daha yüksek olması ve yaş arttıkça heyecan arama düzeylerinin azalma eğilimiyle (Arnett, 1994) açıklamışlardır. 
Özetle, yukarıda sıralanan bütün bu bulgular birbirleriyle tutarlı bir örüntü sunmaktadır. Bu tutarlı bulgu örüntüsünden de heyecan arama düzeyindeki artışın riskli sürücülük eğilimlerinde artışla istatistiksel olarak anlamlı bir düzeyde ilişkili olduğu sonucuna ulaşılabilmektedir. Yukarıda da belirtildiği gibi heyecan arama kişilik özelliğiyle kavramsal olarak yakın olan ve riskli sürücülük ve olumsuz sürücü davranışlarını yordamaya yönelik çalışmalarda sıkça incelen bir diğer kişilik özelliği de dürtüselliktir. Heyecan arama ve dürtüsellik dışadönüklük genel faktörünün alt boyutlarındandır ve dışadönüklüğün kazaya karışmayla ilişkisi de bu iki alt boyutla açıklanmıştır (Eysenck ve Eysenck, 1968; Eysenck ve Eysenck, 1975). Dürtüsellik, hazzı erteleyememe, sonuçlarını düşünmeden harekete geçme ve bu nedenle de olumsuz sonuçlar doğurabilecek uyumsuz davranışları gösterebilme eğilimi olarak tanımlanabilir (Caci, Nadalet, Baylé, Robert, ve Boyer, 2003; Monterosso ve Ainslie, 1999). Dürtüsellik teriminin tepkileri kısitlamada zorlanma, beklemeyi becerememe, olumsuz veya geciken sonuçlara duyarsız olma gibi birçok uyumsuz davranış kullanılmakta olduğu söylenebiliir (de Wit, 2009).

Bireylerin sonuçlarını düşünmeden davranmaya eğilimli olması da onların trafikte araç kullanırken de amacı trafik ortamındaki kendisi de dâhil tüm yol kullanıcıları korumak olan trafik kurallarına uymamasına neden olabileceği düşüncesiyle dürtüselliğin olumsuz ve riskli sürücülük davranışlarıyla pozitif yönlü ilişkiler göstermesi beklenir. Aynı şekilde eğer dürtüsellik seviyesi yüksek bireyler hızlı araç kullanmaktan keyif alıyorlarsa hazzı erteleyememek konusunda yaşadıkları sorun nedeniyle de yapmamaları gerektiği halde bu davranışı gösterme eğiliminde olacaklardır.

Alanyazında dürtüsellik ve sürücülük ilişkisini inceleyen çalışmaların sistematik derleme çalışması Bıçaksız ve Özkan (2016a) tarafından yürütülmüştür. Bu derleme çalışmasına dâhil edilen toplam 38 çalışmadan 34'ünde dürtüsellik kişilik özelliği ve sürücülükle ilgili değişkenler arasında istatistiksel olarak anlamlı ilişki bulunmuştur. Dürtüselliğin öz-beyana dayalı ölçülmüş olan sürücü hataları, kural ihlalleri, trafikte öfke ve saldırganlık, alkol ve madde etkisi altında araç kullanma, trafik cezası ve kazaya karışma sayısı, araç kullanma simulatöründe ölçülmüş olan riskli sürücü davranışları gibi değişkenlerle pozitif yönlü ilişkileri gözlenmiştir. $\mathrm{Bu}$ derleme çalışmasının başka bir bulgusu ise dürtüselliğin de kazaya karışma sayısıyla ilişkisinin sürücü davranışlarıyla ilişkisine kıyasla daha zayıf olduğudur. $\mathrm{Bu}$ da yine bağlamsal aracılı modeli destekler niteliktedir.

İşlevsel ve işlevsiz dürtüselliğin sürücü davranışlarıyla farklılık gösteren ilişkileri Türk sürücü örneklemiyle yürütülen bir çalışmada (Bıçaksız ve Özkan, 
2016b) incelenmiştir. Bu çalışmada olumsuz/sapkın sürücü davranışlarına ek olarak olumlu sürücü davranışları da incelenmiştir. Olumlu sürücü davranışları ise güvenlik kaygısı taşıyarak ya da taşımaksızın genel trafik ortamına ve diğer yol kullanıcılarına yardımcı olmak amacıyla yapılan davranışlar olarak tanımlanmaktadır (Özkan ve Lajunen, 2005a). Çalışmanın bulguları, işlevsiz dürtüselliğin, yani alanyazında genel olarak dürtüsellik olarak geçen ve olumsuz sonuçlara neden olan uyumsuz davranış eğilimleri olarak tanımlanan kişilik özelliğinin, sürücü hataları ve kural ihlalleriyle pozitif yönlü, olumlu sürücü davranışlarıyla da negatif yönlü ilişkili olduğunu göstermiştir. Ancak işlevsel dürtüselliğin hatalarla ilişkisi negatif yönlü, kural ihlalleriyle ilişkisi istatistiksel olarak anlamsız, olumlu sürücü davranışlarıyla ilişkisi ise pozitif yönlüdür. Bu da işlevsel ve işlevsiz dürtüselliğin sürücü davranışlarıyla ilişki örüntüsünün farklılaştığını göstermekte ve işlevsiz dürtüselliğin sürücü davranışlarını açıklamaya yönelik modellere dâhil edilmesinin önemini göstermektedir.

Özetle, hem dürtüsellik hem de heyecan arama kişilik özelliklerinin olumsuz sürücü davranışlarıyla ilişkilerinin pozitif yönlü olduğu ve bu ilişkinin alanyazındaki çalışmalarda tutarlı olarak gözlendiği söylenebilir. Başka bir deyişle bu kişilik özelliklerinde yüksek düzeyler daha olumsuz ve riskli sürücü davranışlarında artışla ilişkilidir. $\mathrm{Bu}$ nedenle bu kişilik özelliklerinin riskli sürücülüğü açıklamayı hedefleyen modellerde yer alması önemlidir. Uygulamada ise bu özelliğe yüksek düzeyde sahip olan bireylere yönelik farkında olma ve bu farkındalıkla güvenli sürücülük eğitimleri gibi müdahale programları geliştirilmesi ve bu programların sürücülüğe adım atılan sürücü kursları sistemine entegre edilmesi önerilebilir.

\section{KARANLIK ÜÇLÜ KISŞILİK MODELİ (“DARK TRIAD”)}

Karanlık Üçlü kişilik modeli narsisizm, psikopati ve Makyavelizm'den oluşmaktadır ve bu üç kişilik özelliği birbirleriyle ilişkili olup üçünde de ortak görülen saldırganlık, düzenbazlık ve duygusal soğukluk gibi kötücül eğilimler bulunmaktadır (Paulhus ve Williams, 2002). Narsisizm kişiler arası ilişkilerde istismarcı eğilimler göstermek, dikkat çekmek için çok fazla çaba göstermek, aşırı derecede kendine odaklılık ve düşük empati düzeyi ile tanımlanmaktadır (Jakobwitz ve Egan, 2006). Psikopati ise yine düşük empati ve kaygı düzeyi, yüksek dürtüsellik ve macera arama düzeyi gibi niteliklerden oluşmaktadır (Paulhus ve Williams, 2002). Son olarak Makyavelizm'in temel unsurları ise kendi çıkarları için başkalarını kullanan, duygusuz ve stratejik bir yönelime sahip olmak olarak sıralanmaktadır (Jones ve Paulhus, 2014). Karanlık üçlü kişilik modeli 
antisosyal doğasıyla genel riskli davranışları yordamaktadır (Malesza ve Ostaszewski, 2016). Bu nedenle Karanlık Üçlü kişilik özelliklerinin riskli sürücü davranışlarıyla da ilişkili olması öngörülerek görece sınırlı sayıda da olsa sürücülük bağlamında çalışmalar yürütülmüştür.

Karanlık Üçlü kişilik özellikleriyle riskli sürücülükle ilgili tutumlar arasındaki ilişkiler 475 sürücü adayıyla yürütülen bir çalışmada incelenmiştir (Endriulaitiene, Šeibokaite, Zardeckaite-Matulaitiene, Markšaityte, ve Slavinskiene, 2018). Çalışma bulguları, Karanlık Üçlü kişilik özelliklerinde yüksek puanlara sahip bireylerin alkollü araç kullanma, kural ihlalleri ve hız yapma gibi riskli davranışlara karşı daha olumlu tutumlara sahip olduğunu göstermiştir.

Başka bir çalışmada (Monteiro, Coelho, Hanel, Pimentel, ve Gouveia, 2018) Karanlık Üçlü kişilik özellikleriyle kazaya karışma arasındaki ilişkide riskli sürücü davranışlarının aracı rolü incelenmiştir. Narsisizm ve psikopati kişilik özelliklerinin riskli sürücülükle pozitif yönlü ilişkili olduğu ve riskli sürücülüğün bu iki kişilik özelliğiyle kazaya karışma arasındaki ilişkide aracı değişken olduğu rapor edilmiştir.

Karanlık Üçlü kişilik özelliklerinin saldırgan sürücülükle ilişkilerinin incelendiği bir çalışmada (Burtăverde, Chraifö Aniţei, ve Mihăilă, 2016) Karanlık Üçlü kişilik özelliklerinin üçünün de sürücü öfke ifadesi boyutlarından sözel saldırgan ifade ve öfkenin araçla ifadesiyle pozitif yönlü ilişkili; Makyavelizm ve psikopatinin fiziksel saldırgan ifade ile pozitif yönlü ilişkili; ve sadece psikopati özelliğinin de öfkenin uyumlu/olumlu ifadesi ile negatif yönlü ilişkili olduğu rapor edilmiştir. $\mathrm{Bu}$ bulgulara ek olarak, hiyerarşik regresyon analizi kullanılarak Karanlık Üçlü kişilik özelliklerinin beş faktörlü kişilik modeli değişkenlerine bağlı bireysel farklılaşma kontrol edildikten sonra sürücü saldırganlık boyutlarında açıkladıkları varyans incelenmiştir. Bu analizlerin sonuçlarına göre öfkenin sözel ifadesi boyutunda narsisizm ve psikopati; öfkenin fiziksel ifadesinde Makyavelizm ve psikopati; öfkenin araçla ifadesinde ise sadece psikopati beş faktörlü kişilik modeli kontrol edildikten sonra bile ilgili saldırganlık boyutuyla istatistiksel olarak anlamlı pozitif yönlü ilişkiler göstermiştir. Bu bulgular da Karanlık Üçlü kişilik modelinin saldırgan sürücülüğü açıklamada artan geçerliğe ("incremental validity") sahip olduğunu göstermektedir.

Karanlık Üçlü kişilik modelinin sürücü öfkesiyle dolaylı ilişkisini inceleyen bir çalışmada (Ball, Tully, ve Egan, 2018), saldırgan sürücülük düzeyinin bu ilişkideki aracı rolü sınanmıştır. Bulgular, Karanlık Üçlü kişilik özelliklerinin sürücülük öfkesini saldırgan sürücülük üzerinden yordadığını göstermiştir. Buna ek olarak 
korelasyon analizinde Karanlık Üçlü kişilik özelliklerinin hepsinin saldırgan sürücülükle istatistiksel olarak anlamlı pozitif yönlü ilişkili olduğu ancak içlerinde en güçlü ilişkinin psikopati özelliğiyle olduğu gözlenmiştir.

Son olarak, Türk sürücü örneklemiyle yürütülen bir çalışmada (Bıçaksız, 2019), Karanlık Üçlü kişilik özellikleriyle sürücü hata, ihmal, kural ihlalleri ve olumlu sürücü davranışları arasındaki ilişkiler incelenmiştir. Bulgular, sadece narsisizmin hata ve ihmal davranışlarını istatistiksel olarak anlamlı bir şekilde yordadığını göstermiştir ve bunun sebebinin de narsisizmdeki aşırı derecede kendine odaklı olma eğiliminin (Jakobwitz ve Egan, 2006) araç kullanırken de dikkat süreçlerini etkiliyor olabileceği ve bu nedenle narsisizmin, bilişsel süreçlerden kaynaklı olan hatalar ve ihmallerle pozitif yönlü ilişki göstermiş olabileceği öne sürülmüştür. Suradan ihlal boyutunda Makyavelizm ve narsisizm, saldırgan ihlal boyutunda ise sadece Makyavelizm'in pozitif yönlü olarak yordayıcı rolünün istatistiksel olarak anlamlı olduğu rapor edilmiştir. Son olarak, olumlu sürücü davranışlarında sadece narsisizmin pozitif yönlü ilişkisi gözlenmiştir. Bu bulgu ise Karanlık Üçlü kişilik özellikleri içinde sadece narsisizme özgü olan başkalarının hayranlığını kazanma çabası eğiliminin (Morf ve Rhodewalt, 2001) trafikte de daha çok olumlu davranış sergileme eğilimiyle ilişkili olabileceğiyle açıklanmıştır.

Özetle, Karanlık Üçlü kişilik modelinin görece sınırlı sayıda çalışmayla da olsa sürücülükle ilgili değişkenlerle ilişkili olduğu gözlenmiştir. Riskli sürücülük, saldırgan sürücülük, sürücü hata, ihmal ve kural ihlalleri gibi sürücülükle ilgili değişkenlerle Karanlık Üçlü kişilik özellikleri arasındaki tutarlı olarak pozitif yönlü olan ilişkiler, bu modelin sürücülük bağlamında kişiliği inceleyen çalışmalarda kullanılmasının alanyazına katkı yapma potansiyeline sahip olduğunu göstermektedir.

\section{KONTROL ODAĞI}

Kontrol odağı terimi ilk olarak Rotter tarafından kişilerin kendi yeterlilikleriyle ilgili kalıcı inançlarını yansıtan bir kişilik özelliği olarak ortaya konulmuştur (Reknes, Visockaite, Liefooghe, Lovakov, ve Einarsen, 2019) ve pekiştireçlerin içsel ya da dışsal kontrolüne dair beklentileri yansıtır (Rotter, 1966). Kendi davranışlarının ödül veya pekiştireçleri belirlediğine dair inanca sahip bireylerin iç kontrol odağına, kendi davranışları dışındaki güçlerin (Örn., şans, kader, vb.) bunları belirlediğine inanan bireylerin ise dış kontrol odağına sahip oldukları öne sürülmektedir. Rotter'a göre bireylerin gelişimsel süreçteki pekiştirme deneyimlerinin doğasına göre bu boyutta iki uçtan birinde yer almayabilirler ve bu boyutun ortalarına doğru bir noktada olabilirler. Alanyazında genel olarak iç 
kontrol odağının, öznel iyilik hali ve stresle başa çıkabilmeyle ilişkili olduğu gözlenmiştir (Örn., Klonowicz, 2001; Petrosky ve Birkimer, 1991).

Kontrol odağ1 değişkenini sürücülük bağlamında inceleyen ilk çalışmalarda karışık bulgulara rastlanmaktadır. Örneğin, bazı çalışmalarda iç kontrol odağının kazaya karışmayla negatif yönlü ilişkili; güvenli ve temkinli sürücülükle pozitif yönlü ilişkili olduğu gözlenmiştir (Örn., Arthur, Barrett, ve Alexander, 1991; Lajunen ve Summala, 1995; Montag ve Comrey, 1987). Öte yandan iç kontrol odağının tehlikeli ve riskli sürücülükle pozitif yönlü ilişkili olduğunu (Hammond ve Horswill, 2002; Horswill ve McKenna, 1999), ya da kontrol odağı değişkeninin sürücülükle istatistiksel olarak anlamlı bir ilişkisi olmadığını (Örn., Arthur ve Doverspike, 1992; Guastello ve Guastello, 1986; Iversen ve Rundmo, 2002) rapor eden çalışmalar da bulunmaktadır.

$\mathrm{Bu}$ karışık bulguların alana özel ölçümle üstesinden gelinebileceğini önererek Özkan ve Lajunen (2005b) Trafik Kontrol Odağı Ölçeğini geliştirmişlerdir. Bu ölçek sürücülerin trafikte meydana gelebilecek kazaların nedenlerini, kendisi/kendi eylemleri, araç ve çevre koşulları, kader ve diğer sürücüler gibi faktörlerden her birine ne düzeyde atfettiklerini ölçmektedir. Kendi eylemlerine atıf alt boyutu iç kontrol odağını yansıtmakta ve diğer üç boyut da dış kontrol odağını yansıtmaktadır. Toplam 348 Türk üniversite öğrencisi sürücüyle yürütülen bu ölçek geliştirme çalışmasında iç kontrol odağının (kendi/kendi eylemleri) öz-beyana dayalı ölçülmüş olan toplam kazaya karışma sayısı, trafik cezası sayısı, saldırgan ve sıradan ihlaller ve sürücü hataları arasında pozitif yönlü ilişkileri gözlenmiştir. Buna ek olarak, olası kazaların nedenlerini araç ve çevre koşullarına atfetme eğiliminin sürücü hatalarıyla pozitif yönlü, trafik cezası sayısıyla da negatif yönlü ilişskili olduğu bulunmuştur. Son olarak olası kazaların nedenlerini diğer sürücülere atfetme eğilimin ise sürücü hatalarıyla negatif yönlü ilişkili olduğu gözlenmiştir. Araştırmacılar, sürücülükle ilgili becerilerine aşırı güvenen sürücülerin meydana gelebilecek bir kazanın kendi kontrollerinde olduğunu düşünme eğilimlerinden dolayı (trafikte) iç kontrol odağı yöneliminde olabileceklerini ve bu tür bir yüksek özgüven seviyesinin de riskli sürücü davranışlarıyla ilişkili olabileceğini öne sürmüşlerdir.

İsveçli sürücü örneklemiyle yürütülen bir çalışmada (Warner, Özkan, ve Lajunen, 2010) yine sürücülerin olası kazaların nedenlerini kendi davranışlarına atfetme yönelimi (trafikte iç kontrol odağı) hız yapma davranışıyla pozitif yönlü ilişsili, hız limitlerine uyma ile de negatif yönlü ilişkili olduğu bulunmuştur. Ayrıca, olası kazaların nedenlerin araç ve çevreye atfetme yöneliminin hız 
limitlerine uyma ile pozitif yönlü ilişkisi gözlenmiştir. Bu bulgular Özkan ve Lajunen'in (2005) bulgulariyla uyumludur.

Görece büyük bir sürücü örneklemiyle $(N=1638)$ yürütülen bir çalışmada (Sarma, Carey, Kervick, ve Bimpeh, 2013) trafikte kontrol odağının riskli sürücülük, hız yapma ve kural ihlali, temkinli sürücülük, alkollü araç kullanma ve tehlikeli araç kullanma gibi değişkenlerle ilişkileri incelenmiştir. Bulgular, olası kazaların nedenlerini kendi davranışlarına atfetme yöneliminin (trafikte iç kontrol odağı) tehlikeli sürücülükle pozitif yönlü ilişkili olduğunu göstermiştir. Trafikte meydana gelebilecek kazaların nedenlerini kadere atfetme eğilimi (trafikte diş kontrol odağı) ise hız yapma ve kural ihlali ve tehlikeli sürücülük değişkenleriyle negatif yönlü ilişki göstermiştir. Olası kazaların nedenlerini diğer sürücülere ve araç ve çevre koşullarına atfetme eğilimlerinin (trafikte dış kontrol odağı) ise temkinli sürücülük ile pozitif yönlü ilişkili olduğu ancak emniyet kemeri kullanma ile negatif yönlü ilişkili olduğu gözlenmiştir. Bu son bulgular kendi içinde de tutarsız görünmektedir ve araştırmacılar emniyet kemeri kullanma temkinli sürücülükle yürütülen çalışmadaki tüm analizlerde model uyumunun düşük olduğunu belirtmişlerdir. Ancak bu bulgular dışındaki bulgular alanyazındaki Trafikte Kontrol Odağı kullanılarak yürütülen diğer çalışmalarla uyumlu niteliktedir.

Kontrol odağ1 ve riskli sürücülük ilişkisini inceleyen en yeni çalışmalardan birinde (Lemarié, Bellavance, ve Chebat, 2019), iç kontrol odağı, güçlü insanlara atıf ve şansa atıf boyutlarından oluşan kontrol odağı ölçeği (Levenson, 1981) kullanılmıştır. Lojistik regresyon analizi sonuçları iç kontrol odağına sahip olmanın yüksek risk sürücüler grubunda olma olasılığını artırdığını göstermiştir. Yüksek risk ve düşük risk sürücüler grupları ise resmi kanallardan alınan sürücülükle ilgili kayıtlar doğrultusunda oluşturulmuştur. Bu çalışmada elde edilen iç kontrol odağının riskli sürücülükle ilişkili olduğu bulgusu da yine alanyazındaki son dönem çalışmaları destekler niteliktedir.

Sonuç olarak kontrol odağının sürücülük bağlamında incelendiği ilk çalışmalarda birbirleriyle tutarsız bulgulara rastlanmaktadır ancak bu kavram sürücülük bağlamına uyarlanarak ölçülmeye başlandıktan sonra yürütülen çalışmalarda genel tutarlı bir örüntü görülmektedir. $\mathrm{Bu}$ da trafikte iç kontrol odağının riskli sürücülükle, dış kontrol odağının ise güvenli sürücülükle ilişkili olduğu bulgular örüntüsüdür. 


\section{SONUÇ}

$\mathrm{Bu}$ çalışmada sunulan araştırma bulgularından yola çıkarak genel olarak kişilik özelliklerinin sürücülükle ilgili davranışlardaki varyansı açıklamada önemli katkı yaptığı söylenebilir. Başka bir deyişle, kişilik, sürücü davranışlarını yordayan önemli faktörlerden birisidir. Bu çalışmada sürücülük bağlamında en yaygın olarak incelenmiş olan belli başlı kişilik özellikleri ve bunların sürücülükle ilişkileri bir araya getirilerek sunulmuştur. Uzun yıllar boyunca çok yaygınca araştırılmış olan kişilik özellikleri için (Örn., beş faktörlü kişilik modeli, heyecan arama, dürtüsellik, treyt öfke) bireysel çalışmalar yerine sistematik literatür çalışmaları veya metaanaliz çalışmalarına yer verilmiştir. Öte yandan, görece sınırlı çalışmalar bulunan kişilik özellikleri için (Örn., Karanlık Üçlü kişilik özellikleri, kontrol odağı) ise ulaşılabilen tüm bireysel çalışmalar sunulmuştur. Buna ek olarak, her bir kişilik değişkeni için Türk sürücü örneklemiyle yürütülmüş olan en yakın tarihli çalışmalar da dâhil edilmiştir. Ancak belirtilmelidir ki da bu çalışmanın amacı sürücülük bağlamında kişilik yazınındaki sayısız çalışmanın sistematik bir literatür taramasını yapmak değil, genel bulgu ve sonuçları bir araya getirmek ve okuyucuya genel bir özet bilgi sunmaktır. Bu nedenle bu derleme çalışmasına dâhil edilmemiş kuşkusuz çok sayıda bireysel çalışmanın olduğunun hatırlatılması ve dâhil edilmeyen çalışmalarla ilgili niyetli bir seçim yapılmadığının vurgulanması gerekmektedir.

Kişilik özelliklerinin riskli sürücülük davranışlarını açıklamaya yönelik önemli katkı sağladığı sonucunun alanda uygulamaya yönelik doğurguları ise kısıtlıdır. Öncelikle kişilik değiştirip dönüştürülmesi çok da kolay olmayan bir faktördür. Buna ek olarak, belli kişilik özelliklerine sahip olan ya da bu özelliklerin boyut olarak ölçüldüğünde belli düzeylerde puanlar alan bireylerin trafiğe çıkma haklarını ellerinden almak da mümkün görünmemektedir. $\mathrm{Bu}$ durumda olas1 müdahalenin sürücü kursu ve ehliyet alma sistemlerine entegre edilmesi önerilebilir (Jonah, 1997). Sürücü belgesi almak üzere başvuruda bulunan sürücü adaylarına bu kişilik özelliklerine yönelik ölçekler uygulanarak riskli sürücülükle iliş̧kili olan kişilik özelliklerinde bireylerin puanları belirlenebilir. Bu çalışmanın genel sonuçları doğrultusunda treyt öfke, heyecan arama, dürtüsellik, trafikte iç kontrol odağ 1 ve narsisizm kişilik özelliklerinde yüksek puanlara sahip olan sürücü adaylarına yönelik bu kişilik özelliklerinin hangi davranışlarda kendini gösterebileceği ve sürücülükle ilgili ne gibi olası olumsuz sonuçlarla ilişkili olabileceğine dair bilgilendirme ve farkındalık geliştirmeyi hedefleyen içerikler oluşturularak müdahale programları geliştirilebilir. Örneğin, Paaver ve arkadaşları 
(2013) dürtüsellik ve dürtüsel davranışlara yönelik farkındalık eğitimi geliştirmiş ve bu eğitim programını sürücü kursunda eğitim almakta olan sürücü adaylarına uygulamışlardır. $\mathrm{Bu}$ eğitim programının içeriğinde bir kişilik özelliği olarak dürtüselliğin tanımı, türleri ve biyolojik temelleri; risk alma davranışıyla ilişkisi; kişinin kendisindeki dürtüsel eğilimleri nasıl fark edebileceği; dürtüsel davranışın olası tetikleyicileri; öz-denetim ve öz-düzenleme süreçleri gibi konular yer almıştır. Sürücü belgelerini aldıktan bir yıl sonra bu eğitime katılan deney grubu ve katılmayan kontrol grubunun trafik ceza sayıları karşılaştırıldığında eğitime katılmış olan grubun katılmamış olan kontrol grubuna kıyasla istatistiksel olarak anlamlı düzeyde daha az hız cezası aldığı gözlenmiştir. Buna benzer programların geliştirilmesi ve ülkemizdeki sürücü kursu sistemine entegre edilmesi çok da zor ve pahalı görünmemektedir.

Yol güvenliğini ciddi tehdit eden trafik kazaları gibi ülkemizde ciddi bir halk sağlığı sorunu teşkil eden bir konuda en temel unsurlardan biri olan insan faktörünü açıklamada önemli role sahip olan kişilik değişkenlerinin bu bağlamda incelenmesi, gerekli müdahale programları geliştirilerek yol güvenliğini artırmaya katk1 sağlama potansiyeline sahiptir. Bu çalışma da ülkemizde bu konuda yürütülecek çalışmalara yol göstermeye ve bu sayede yol güvenliğine katkıda bulunmaya yönelik naçizane bir çabayı temsil etmektedir. 


\section{KAYNAKÇA}

Akbari, M., Lankarani, K. B., Heydari, S. T., Motevalian, S. A., Tabrizi, R., AsadiShekari, Z., \& Sullman, M. J. M. (2019). Meta-analysis of the correlation between personality characteristics and risky driving behaviors. Journal of Injury Violence Research, 11, 107-122.

Arnett, J. (1994). Sensation Seeking: A new conceptualization and a new scale. Personality and Individual Differences, 16, 289-296.

Arthur, W., Barrett, G. V., \& Alexander, R. A. (1991). Prediction of vehicular accident involvement: A meta-analysis. Human Performance, 4, 89-105. http://dx.doi.org/10.1207/s15327043hup0402_1.

Arthur, W., \& Doverspike, D. (1992). Locus of control and auditory selective attention as predictors of driving accident involvement: A comparative longitudinal investigation. Journal of Safety Research, 23, 73-80. http://dx.doi.org/10.1016/0022-4375(92)90023-3.

Arthur, W., \& Graziano, W. G. (1996). The five-factor model, concscientiousness, and driving accident involvement. Journal of Personality, 64, 593-618.

Averill, J. R. (1982). Anger and aggression: An essay on emotion. New York: Springer/Verlag.

Ball, L., Tully, R., \& Egan, V. (2018). The influence of impulsivity and the Dark Triad on self-reported aggressive driving behaviours. Accident Analysis and Prevention, 120, 130-138.

Bıçaksız, P., \& Özkan, T. (2016a). Impulsivity and driver behaviors, offences and accident involvement: A systematic review. Transportation Research Part F: Psychology and Behaviour, 38, 194-223. doi: http://dx.doi.org/10.1016/j.trf.2015.06.001

Bıçaksız, P. (2019). Karanlık üçlü kişilik özellikleri ve sürücü davranışları arasındaki ilişkilerin incelenmesi. Trafik ve Ulaşım Araştırmaları Dergisi, 2(2), 66-77.

Biçaksız, P., \& Özkan, T. (2016b). Developing the Impulsive Driver Behavior Scale. Transportation Research Part F: Psychology and Behaviour, 43, 339356. doi: http://dx.doi.org/10.1016/j.trf.2016.09.005 
Bogdan, S. R., Mairean, C., \& Havârneanu, C. E. (2016). A meta-analysis of the association between anger and aggressive driving. Transportation Research Part F: Psychology and Behaviour, X, X-X.

Burtăverde, V., Chraif, M., Aniţei, M., \& Mihăil, T. (2016). The incremental validity of the dark triad in predicting driving aggression. Accident Analysis and Prevention, 96, 1-11.

Caci,H., Nadalet, L., Baylé, F. J., Robert, P., \& Boyer, P. (2003). Functional and dysfunctional impulsivity: Contribution to the construct validity. Acta Psychiatrica Scandinavica, 107 (1), 34-40.

Clarke, S., \& Robertson, I. T. (2005). A meta-analytic review of the Big Five personality factors and accident involvement in occupational and nonoccupational settings. Journal of Occupational and Organizational Psychology, 78, 355-376.

Costa, P. T. Jr., \& McCrae, R. R. (1992). The NEO Personality Inventory manual. Psychological Assessment Resources, Odessa, FL.

Craske, S. (1968). A study of the relationship between personality and accident history. British Journal of Medical Psychology, 41, 399-404.

Dahlen, E.R., Edwards, B.D., Tubré, T., Zyphur, M.J., Warren, C.R., (2012). Taking a look behind the wheel: an investigation into the personality predictors of aggressive driving. Accident Analysis and Prevention, 45, 1-9.

Deffenbacher, J. L. (2016). A review of interventions for the reduction of driving anger. Transportation Research Part F, 42, 411-421

Deffenbacher, J. L., Deffenbacher, D. M., Lynch, R. S. ve Richards, T. L. (2003). Anger, aggression, and risky behavior: a comparison of high and low anger drivers. Behaviour Research and Therapy, 41, 701-718.

Deffenbacher, J.L., Huff, M.E., Lynch, R.S., Oetting, E.R., Salvatore, N.F. (2000). Characteristics and treatment of high-anger drivers. Journal of Counseling Psychology 47, 5-17, doi:10.1037/0022-0167.47.1.5.

Deffenbacher, J.L., Lynch, R.S., Oetting, E.R., Swaim, R.C. (2002). The Driving Anger

Deffenbacher, J.L., Lynch, R.S., Oetting, E.R., Yingling, D.A., (2001). Driving anger: Correlates and a test of state-trait theory. Personality and Individual Differences 31, 1321-1331, doi:10.1016/S0191-8869(00)00226-9. 
Deffenbacher, J.L., Oetting, E.R., Lynch, R.S., (1994). Development of a driving anger scale. Psychological Reports 74, 83-91.

Demir, B., Demir, S., \& Özkan, T. (2016). A contextual model of driving anger: a meta-analysis. Transportation Research Part F: Traffic Psychology and Behaviour, 42, 332-349.

De Wit, H. (2009). Impulsivity as a determinant and consequence of drug use: A review of underlying processes. Addiction Biology, 14, 22-31. doi:10.1111/j.1369-1600.2008.00129.x

Dickman, S. J. (1990). Functional and dysfunctional impulsivity: personality and cognitive correlates. Journal of Personality and Social Psychology, 58, 95-102.

Endriulaitiene, A., Šeibokaite, L., Zardeckaite-Matulaitiene, K., Markšaityte, R., \& Slavinskiene, J. (2018). Attitudes towards risky driving and Dark Triad personality traits in a group of learner drivers. Transportation Research Part F, $56,362-370$.

Eşiyok, B., Yasak, Y., \& Korkusuz, İ. (2007). Trafikte Öfke İfadesi: Sürücü Öfke İfadesi Envanteri'nin geçerlik ve güvenirliği. Türk Psikiyatri Dergisi, 18(3), 231-243.

Evans, L. (1996). Comments: The dominant role of driver behavior in traffic safety. American Journal of Public Health, 86(6), 784-786.

Eysenck, H. J. (1970). The personality of drivers and pedestrians. Medicine, Science and the Law, 3, 416-423.

Eysenck, H.J. (1983) A biometrical-genetical analysis of perception of traffic signs and driver violations and accidents. Accident Analysis and Prevention, 11, 125127.

Eysenck. H. J., \& Eysenck, S. B. G. (1968). Manual for the Eysenck Personality Inventory. San Diego: Educational and Industrial Testing Service.

Eysenck, H. J., \& Eysenck, S. B. G. (1975). Manual of the Eysenck Personality Questionnaire. London: Hodder and Stoughton.

Expression Inventory: A measure of how people express their anger on the road. Behaviour Research and Therapy 40, 717-737, doi:10.1016/S00057967(01)00063-8. 
Goldberg, L.R., 1993. The structure of phenotypic personality traits. American Psychologist 48, 26-34, doi:10.1037/0003-066X.48.1.26.

Guastello, S. J., \& Guastello, D. D. (1986). The relation between locus of construct and involvement in traffic accidents. The Journal of Psychology, 120(3), 293297. http://dx.doi.org/10.1080/00223980.1986.10545255.

Hammond, T. B., \& Horswill, M. S. (2002). The influence of desire for control on drivers' risk-taking behavior. Transportation Research Part F, 4, 271277.http://dx.doi.org/10.1016/S1369-8478(01)00028-6.

Horswill, M. S., \& McKenna, F. P. (1999). The effect of perceived control on risk taking. Journal of Applied Social Psychology, 29(2), 377-391. http://dx.doi.org/10.1111/j.1559-1816.1999.tb01392.x.

Horvarth, P., \& Zuckerman, M. (1993). Sensation seeking, risk appraisal, and risky behavior. Personality and Individual Differences, 14, 41-52.

Iversen, H., \& Rundmo, T. (2002). Personality, risky driving and accident involvement among Norwegian drivers. Personality and Individual Differences, 33, 1251-1263. http://dx.doi.org/10.1016/S0191-8869(02)00010-7.

Izard, C. E. (1994). Innate and univerdal facial expression - evidence from developmental and cross-cultural research. Psychological Bulletin, 115, 288299.

Jakobwitz, S., \& Egan, V. (2006). The dark triad and normal personality traits. Personality \& Individual Differences, 40(2), 331-339.

Jonah, B. A. (1997). Sensation seeking and risky driving: A review and synthesis of the literature. Accident Analysis and Prevention, 29, 651-665.

Jones, D. N., \& Paulhus, D. L. (2014). Introducing the short dark triad (SD3) a brief measure of dark personality traits. Assessment, 21, 28-41.

Kassinove, H., \& Tafrate, R. C. (2006). Anger-related disorders: Basic issues, models and diagnostic considerations. In E. L. Feindler (Ed.), Anger-related disorders (pp. 1-27). New York: Springer.

Klonowicz, T. (2001). Discontented people: Reactivity of locus of control as determinants of subjective well-being. European Journal of Personality, 15 (1), 29-47. 
Lajunen, T., \& Summala, H. (1995). Driving experience, personality, and skill and safety-motive dimensions in drivers"e self-assessments. Personality \& Individual Differences, 19(3), 307-318.

Lemarié, L., Bellavance, F., \& Chebat, J. (2019). Regulatory focus, time perspective, locus of control and sensation seeking as predictors of risky driving behaviors. Accident Analysis and Prevention, 127, 19-27.

Levenson, H. (1981). Differentiating among internality, powerful others, and chance.In H. M. Lefcourt (Ed.), Research with the locus of control construct (Vol. 1, pp. 15-63). New York: Academic Press.

Loo, R. (1979). Role of primary personality factors in the perception of traffic signs

and driver violations and accidents. Accident Prevention and Analysis, 17, 449460.

Malesza, M., \& Ostaszewski, P. (2016). The utility of the Dark Triad model in the prediction of the self-reported and behavioral risk-taking behaviors among adolescents. Personality \& Individual Differences, 90, 7-11.

Mayer, R. E., \& Treat, J. R. (1977). Psychological, social and cognitive characteristics of high-risk drivers: A pilot study. Accident Analysis and Prevention, 9, 1-8.

Montag, I., \& Comrey, A. L. (1987). Internality and externality as correlates of involvement in fatal driving accidents. Journal of Applied Psychology, 72, 339343.

Monteiro, R. P., Coelho, G. L. H., Hanel, P. H. P., Pimentel, C. E., \& Gouveia, V. V. (2018). Personality, dangerous driving, and involvement in accidents: Testing a contextual mediated model. Transportation Research Part F, 58, 106-114.

Monterosso, J., \& Ainslie, G. (1999). Beyond discounting: possible experimental models of impulse control. Psychopharmacology, 146, 339-347.

Morf, C.C. \& Rhodewalt, F. (2001), Unraveling the paradoxes of narcissism: A Dynamic self-regulatory processing model. Psychological Inquiry, 12, 177196.

Näätänen, R., \& Summala, H. (1976). Road User Behavior and Traffic Accidents. North-Holland/American Elsevier: Amsterdam/New York. 
Nesbit, S. M., Conger, J. C., \& Conger, A. J. (2007). A quantitative review of the relationship between anger and aggressive driving. Aggression and Violent Behavior, 12, 156-176.

Özkan, T., \& Lajunen, T. (2005a). A new addition to DBQ: Positive driver behaviour scale. Transportation Research Part F: Traffic Psychology and Behaviour, 8, 355-368. doi:10.1016/j.trf.2005.04.018

Özkan, T., \& Lajunen, T. (2005b). Multidimensional Traffic Locus of Control Scale (T-LOC): factor structure and relationship to risky driving. Personality and Individual Differences, 38, 533-545.

Paaver, M., Eensoo, D., Kaasik, K., Vaht, M., Mäestu, J., \& Harro, J. (2013). Preventing risky driving: A novel and efficient brief intervention focusing on acknowledgement of personal risk factors. Accident analysis and Prevention, $50,430-437$

Paulhus, D. L. \& Williams, K. M. (2002). The Dark Triad of personality: Narcissism, Machiavellianism, and psychopathy. Journal of Research in Personality, 36, 556-563.

Petrosky, M. J., \& Birkimer, J. C. (1991). The relationship among locus of control, coping styles, and psychological symptom reporting. Journal of Clinical Psychology, 47, 336-345.

Plutchik, R. (1994). The psychology and biology of emotion. New York: HarperCollins.

Reason, J. T., Manstead, A., Stradling, S. G., Baxter, J., \& Campbell, K. (1990). Errors and violations on the road - A real distinction. Ergonomics, 33(10/11), $1315-1332$.

Reeve, C. L. (2007). Functional impulsivity and speeded ability test performance. International Journal of Selection and Assessment, 15(1), 56-62.

Reknes, I., Visockaite, G., Liefooghe, A., Lovakov, A., ve Einarsen, S. V. (2019). Locus of control moderates the relationship between exposure to bullying behaviors and psychological strain. Frontiers in Psychology, 10, 1-12. https://doi.org/10.3389/fpsyg.2019.01323

Rotter, J. B. (1966). Generalized expectancies for internal vs. external control of reinforcement. Psychological Monographs, 80, 1-28. 
Sarma, K. M., Carey, R. N., Kervick, A. A., \& Bimpeh, Y. (2013). Psychological factors associated with indices of risky, reckless and cautious driving in a national sample of drivers in the Republic of Ireland. Accident Analysis and Prevention, 50, 1226-1235.

Selzer, M. L., Rogers, J. E., \& Kern, S. (1968). Fatal accidents: The role of psychopathology, social stress and acute disturbance. American Journal of Psychiatry, 124, 1028-1036.

Spielberger, C.D., (1988). State-Trait Anger Expression Inventory. Psychological Assessment Resources, Odessa, FL.

Sümer, N. (2003). Personality and behavioral predictors of traffic accidents: Testing a contextual mediated model. Accident Analysis and Prevention, 35, 949-964.

Sümer, N., Lajunen, T., \& Özkan, T. (2005). Big five personality traits as the distal predictors of road accident involvement. (Ed.) G. Underwood. Ch. 18, Traffic and Transport Psychology. Elsevier Ltd.

Sümer, N., \& Özkan, T. (2002). Sürücü davranışları, becerileri, bazı kişilik özellikleri ve psikolojik belirtilerin trafik kazalarındaki rolleri. Türk Psikoloji Dergisi, 17 (50), 1-22.

Warner, H. W., Özkan, T., \& Lajunen, T. (2010). Can the traffic locus of control (T-LOC) scale be successfully used to predict Swedish drivers' speeding behaviour? Accident Analysis and Prevention, 42, 1113-1117. http://dx.doi.org/10.1016/j.aap.2009.12.025.

Whiteside, S. P., \& Lynam, D. R. (2001). The Five Factor Model and impulsivity: using a structural model of personality to understand impulsivity. Personality and Individual Differences, 30, 669-689.

World Health Organization (2008). World health statistics 2008. Retrieved from: www.who.int/whosis/whostat/2008/en/index.html

Word Health Organization (2014) The 10 Leading Causes of Death in the World, 2000 and 2012, retrieved from; http://www.who.int/mediacentre/factsheets/fs310/en

World Health Organization (2018). "Global status report on road safety 2018" retrieved from https://www.who.int/violence_injury_prevention/road_safety_status/2018/en/ 
Yasak, Y., \& Eşiyok, B. (2009). Anger amongst Turkish drivers: Driving Anger Scale and its adapted, long and its adapted, long and short version. Safety Science, 47(1), 138-144.

Yasak Y., Eşiyok B., Başbulut A. Z., \& Korkusuz, I. (2005) Trafikte öfke: Sürücü Öfke Ölçeği’nin (SÖÖ) geçerlik ve güvenirliği. Trafik ve Yol Güvenliği 3. Ulusal Kongresi, 4-6 Mayıs, Gazi Üniv. Ankara.

Zhang, T., \& Chan, A. H. S. (2016). The association between driving anger and driving outcomes: A meta-analysis of evidence from the past twenty years. Accident Analysis and Prevention, 90, 50-62.

Zuckerman, M. (1994). Behavioral Expressions and Biosocial bases of Sensation Seeking. University of Cambridge Press, Cambridge

Zuckerman, M., Kolin, I., Price, L. and Zoob, I. (1964) Development of a sensation seeking scale. Journal of Consulting Psychology, 28, 477-482. 